\title{
EPIDEMIOLOGICAL EVALUATION OF PATIENTS WITH RHEUMATOID ARTHRITIS TREATED AT CEDMAC IN SÃO JOSÉ DO RIO PRETO AND THEIR PERCEPTION OF THE DISEASE AND TREATMENT
}

Viviane Queiroz de Oliveira Maia ${ }^{1, \star}$, Viviane Alves Costa ${ }^{1}$, Gizelle Gouvea Rezende ${ }^{1}$ Luciana Akita ${ }^{1}$, lane Tamara Dondé ${ }^{1}$ Danielly Dantas Pimentel', Gustavo Roberto Lourenço', Juliana de Jesus Boscolo', Carolina Goulart de Carvalho', Taisa Morete da Silva', Ricardo Acayaba de Toledo'

1.Faculdade de Medicina de São José do Rio Preto, São José do Rio Preto (SP), Brazil.

*Corresponding author: viviane_vi82@yahoo.com.br

\section{BACKGROUND}

Rheumatoid arthritis is a chronic systemic inflammatory disease that affects around $1 \%$ of the world population, if not treated early and properly it can lead to bone and cartilage destruction, culminating in irreversible joint deformities. The High-Cost Medication Centers (CEDMAC) were established aiming at the formation of a state network for the comprehensive care of patients using immunobiological agents, monitoring the dispensing and application of these drugs and assessing the risks and side effects.

\section{MATERIALS AND METHODS}

This is a pilot, cross-sectional, observational study, approved by the institutional research ethics committee under number 3.917.756. A free and informed consent form was applied for participation in the research and a questionnaire for patients with rheumatoid arthritis who received immunobiologicals at CEDMAC in March 2020. Statistical analysis of the data was performed. Statistical analysis was performed using the chi-square method.

\section{RESULTS}

Due to the coronavirus disease 2019 (COVID-19) pandemic, it was only possible to apply questionnaires during one month, since the team was directed to the treatment of patients with COVID 19, resulting in a sample of 45 patients. Among the patients who responded to the survey, the average age was 54 years old, 58\% female and 68\% considered themselves white. The majority are from São José do Rio Preto (64\%), $48 \%$ of users used their own vehicle to go to CEDMAC, $26 \%$ have completed high school and $51 \%$ of patients follow up in a private office. Regarding the disease and its treatment, 55\% consider themselves to have a good degree of knowledge of the disease, $73 \%$ believe that the consultation is the best source of information and $62 \%$ reported that they had participation in choosing the immunobiological. Regarding the use of medication, 87.5\% felt safe at CEDMAC. Of the patients evaluated, only $12 \%$ used intravenous biologics and $77 \%$ had not used any other immunobiologicals previously. There was no statistical correlation between the level of education and the degree of knowledge of the disease or participation in the choice of immunobiological.

\section{CONCLUSION}

The study is biased by the small sample, due to the pandemic of COVID-19, being initially structured as a pilot and, therefore, later we will have data with a larger number of participants. Through this preliminary analysis, it was observed that patients acquired more knowledge of arthritis during consultations than by other informational means and most patients were involved in choosing the immunobiological agent, regardless of the level of education.

\section{REFERENCES}

1. Firestein G, Budd R, Sherine EG, McInnes IB, O'Dell J. Kelley’s Textbook of Rheumatology. 9. ed. Philadelphia: Saunders; 2013.2292 p.

2. Hochberg M, Silman A, Smolen J, Weinblatt M, Weisman M. Rheumatology. 6. ed. Maryland Heights: Mosby Ltd.; 2015.1976 p.

3. Noronha FF, Agostinho HT, Silva HM, Toledo RA. Evolution of the Centers for High Cost Medication in São José do Rio Preto, State of São Paulo: experience report. J Assist Farmac Farmacoecon. 2018;3(1):14-21. https://doi.org/10.22563/2525-7323.2018.v3.n1.p.14-22 